\title{
Analisis Hubungan Kualitas Air Terhadap Indeks Keanekaragaman Plankton dan Bentos Di Waduk Cirata
}

\author{
Ilma Prasiwi dan Eka Wardhani \\ Jurusan Teknik Lingkungan, Fakultas Teknik Sipil dan Perencanaan, Itenas, Bandung \\ Email: ilmaprasiwi@yahoo.co.id
}

\begin{abstract}
ABSTRAK
Waduk Cirata merupakan salah satu danau buatan yang terdapat di Provinsi Jawa Barat. Waduk Cirata terletak berurutan (cascade) diantara Waduk Saguling dan Jatiluhur yang membendung Sungai Citarum. Telah diketahui kualitas air sungai yang masuk ke Waduk Cirata telah tercemar dan menyebabkan kualitas air Waduk Cirata menurun. Berdasarkan hal tersebut maka diperlukan suatu penelitian untuk mengetahui kualitas air menggunakan metode indeks pencemaran dengan indikator plankton dan bentos. Lokasi sampling dilakukan di Sungai Citarum, Cibalagung, Cicendo dan perairan Waduk Cirata di Desa Mande dan Margaluyu. Status mutu air sungai dan air Waduk Cirata dikategorikan cemar sedang. Parameter kualitas air sungai dan perairan Waduk Cirata yang melebihi baku mutu yaitu DO, BOD, Nitrit, Klorin Bebas, Timbal, dan Fenol. Total beban pencemaran dari 3 sungai yang masuk ke Waduk Cirata adalah BOD sebesar 10,839 kg/hari, Nitrit sebesar 0,336 kg/hari, Klorin Bebas sebesar 16,685 kg/hari, Timbal sebesar 0,083 kg/hari dan Fenol sebesar 0,008 kg/hari. Keanekaragaman plankton dan bentos di Desa Mande dan Margaluyu yaitu sedang. Di Desa Mande, spesies yang mendominasi fitoplankton yaitu Volvox sp. dan zooplankton yaitu Brachionus calyciflorus. Sedangkan bentos spesies yang mendominasi yaitu Filopaludina sp. Di Desa Margaluyu, spesies yang mendominasi fitoplankton yaitu Volvox $s p$. dan zooplankton yaitu Moina sp. Sedangkan bentos spesies yang mendominasi yaitu Macrobrachium sp.
\end{abstract}

Kata Kunci: Cirata, Citarum, Kualitas Air, Beban Pencemaran, Plankton, Bentos

\begin{abstract}
Cirata Reservoir is one of the artificial lakes in West Java Province. Cirata Reservoir is located in a cascade between Saguling and Jatiluhur Reservoir which damages the Citarum River. It is known that the quality of river water entering the Cirata Reservoir has been polluted and caused the water quality of the Cirata Reservoir to decrease. Based on this, a study is needed to find out the quality of water using the pollution index method with plankton and benthic indicators. Sampling locations were carried out in the Citarum, Cibalagung, Cicendo and Cirata Reservoir waters in Mande and Margaluyu Villages. The status of river water quality and the water of Cirata Reservoir are categorized as medium pollution. Parameters of river and water quality of the Cirata Reservoir that exceed the quality standards are DO, BOD, Nitrite, Free Chlorine, Lead and Phenol. The total pollution load from the 3 rivers that enter the Cirata Reservoir is BOD of $10.839 \mathrm{~kg} /$ day, Nitrite of $0.336 \mathrm{~kg} /$ day, Free Chlorine of $16.658 \mathrm{~kg} /$ day, Lead of $0.083 \mathrm{~kg} /$ day and Fenol of $0.008 \mathrm{~kg} /$ day. The diversity of plankton and benthos in Mande and Margaluyu villages is medium. In Mande Village, the species that dominates phytoplankton namely Volvox sp. and zooplankton are Brachionus calyciflorus. Whereas the dominating benthic species, Filopaludina sp. In Margaluyu Village, the species that dominate the phytoplankton, Volvox sp. and zooplankton, Moina sp. Whereas the dominating benthic species are Macrobrachium sp.
\end{abstract}

Keywords: Cirata, Citarum, Water Quality, Pollution Load, Plankton, Bentos 


\section{PENDAHULUAN}

Waduk Cirata merupakan salah satu danau buatan yang terdapat di Provinsi Jawa Barat. Pembangunan Waduk Cirata ditujukan untuk memenuhi kebutuhan listrik Jawa-Bali. Waduk Cirata dibangun tahun 1984 dengan cara membendung Sungai Citarum yang berhulu di Gunung Wayang Kabupaten Bandung dan bermuara di Laut Jawa Kabupaten Karawang setelah melalui Kabupaten Bandung, Bandung Barat, Purwakarta dan Karawang. Volume air maksimum waduk ini sebanyak \pm 2.165 juta meter kubik (PT. Pembangkit Jawa Bali Unit Pengelola (PJB UP) Cirata, 2017).

Berkembangnya masyarakat di Daerah Aliran Sungai (DAS) Citarum, berpengaruh terhadap pola pemanfaatan sumber daya alam. Berdasarkan data yang diperoleh dari PT. PJB UP Cirata tahun 2017, status mutu air Waduk Cirata termasuk ke dalam kategori buruk. Parameter yang melebihi baku mutu yaitu $\mathrm{DO}, \mathrm{H}_{2} \mathrm{~S}$, Tembaga $(\mathrm{Cu})$, dan Timbal $(\mathrm{Pb})$. Baku mutu yang dipersyaratkan yaitu Peraturan Pemerintah Nomor 82 Tahun 2001 tentang Pengelolaan Kualitas Air (PKA) dan Pengendalian Pencemaran Air (PPA) untuk kelas II yaitu prasarana/sarana rekreasi air, pembudidayaan ikan tawar, peternakan, pertamanan, dan peruntukkan lain dengan syarat kualitas yang sama.

Waduk Cirata selain berfungsi sebagai Pembangkit Listrik Tenaga Air (PLTA), juga dipergunakan sebagai sumber air irigasi, dan tempat budidaya Keramba Jaring Apung (KJA). Kualitas air suatu badan perairan dapat ditentukan oleh banyak faktor seperti zat terlarut, zat yang tersuspensi dan makhluk hidup yang ada di dalam badan perairan tersebut. Indikator biologi merupakan kelompok atau komunitas organisme yang kehadirannya atau perilakunya di alam berkorelasi dengan kondisi lingkungan. Plankton dan bentos dapat digunakan sebagai indikator biologi dalam suatu badan perairan. Beberapa biota air ini memang mempunyai peranan penting dalam perairan seperti dalam proses dekomposisi dan mineralisasi material organik yang memasuki perairan, serta menduduki beberapa tingkatan trofik dalam rantai makanan (Odum, 1993).

Sehubungan dengan tercemarnya Waduk Cirata maka diperlukan suatu penelitian untuk mengetahui kualitas air Waduk Cirata dan air sungai yang masuk ke waduk tersebut. Penelitian ini dapat memberikan gambaran yang lebih jelas tentang kondisi lingkungan di Waduk Cirata, Kabupaten Purwakarta, Provinsi Jawa Barat. Hasil penelitian diharapkan dapat dijadikan informasi yang berguna bagi masyarakat, dan acuan bagi pengelola Waduk Cirata dalam melakukan pengendalian pencemaran air di perairan tersebut.

\section{METODE PENELITIAN}

\subsection{Lokasi Pengambilan Sampel}

Pengambilan sampel air dilakukan pada tanggal 15 Agustus 2017 mewakili musim kemarau. Jumlah titik pengambilan sampel air, plankton dan bentos untuk di daerah perairan Waduk Cirata di ambil di 2 titik yaitu di Desa Mande dan Margaluyu, sedangkan pengambilan sampel air lainnya di 3 titik sungai yang masuk ke Waduk Cirata yaitu Sungai Citarum, Cibalagung dan Cicendo. Tabel 1 dan Gambar 1 menjelaskan lokasi titik sampling. 
Tabel 1. Lokasi Titik Sampling

\begin{tabular}{|c|c|c|c|}
\hline Titik & Lokasi & Koordinat & Alasan \\
\hline \multicolumn{4}{|l|}{ Sungai } \\
\hline - Citarum & $\begin{array}{l}\text { Jembatan } \\
\text { Rajamandala }\end{array}$ & $\begin{array}{l}6^{\circ} 49^{\prime} 38.05^{\prime} \mathrm{S} \\
107^{\mathrm{O}} 199^{\prime} 22.855^{\prime \prime} \mathrm{E}\end{array}$ & $\begin{array}{l}\text { Merupakan sumber air utama yang } \\
\text { masuk ke Waduk Cirata setelah } \\
\text { Waduk Saguling. }\end{array}$ \\
\hline - Cibalagung & $\begin{array}{l}\text { Jembatan } \\
\text { Jangari }\end{array}$ & $\begin{array}{l}6^{\circ} 44^{\prime} 31.05^{\prime \prime} \mathrm{S} \\
107^{\mathrm{O}} 15,59.99 ” \mathrm{E}\end{array}$ & $\begin{array}{l}\text { Daerah Aliran Sungai terdapat } \\
\text { kegiatan domestik, pertanian dan } \\
\text { peternakan. }\end{array}$ \\
\hline - Cicendo & $\begin{array}{l}\text { Jembatan } \\
\text { Cibogo }\end{array}$ & $\begin{array}{l}6^{\circ} 45^{\prime} 20.16^{\prime \prime} \mathrm{S} \\
107^{\circ} 19^{\prime} 47.80 " \mathrm{E}\end{array}$ & $\begin{array}{l}\text { Merupakan aliran sungai yang dekat } \\
\text { dengan TPA Sarimukti. }\end{array}$ \\
\hline \multicolumn{4}{|l|}{ Genangan Waduk Cirata } \\
\hline $\begin{array}{l}\text { - Mande (Permukaan, } \\
\text { Kedalalaman } 5 \mathrm{~m} \text { dan } 21 \mathrm{~m} \text { ) }\end{array}$ & Desa Mande & $\begin{array}{l}6^{\circ} 43^{\prime} 31.06 " \mathrm{~S} \\
107^{\mathrm{O}} 15^{\prime} 07.97^{\prime \prime} \mathrm{E}\end{array}$ & Merupakan daerah KJA. \\
\hline $\begin{array}{l}\text { - Margaluyu (Permukaan, } \\
\text { Kedalalaman } 5 \text { m dan } 36 \text { m) }\end{array}$ & $\begin{array}{l}\text { Desa } \\
\text { Margaluyu }\end{array}$ & $\begin{array}{l}6^{\circ} 46^{\prime} 24.04 " \mathrm{~S} \\
107^{\circ} 17^{\prime} 44.72 ” \mathrm{E}\end{array}$ & Bukan merupakan daerah KJA. \\
\hline
\end{tabular}

Sumber: Hasil Survey lapangan, 2017

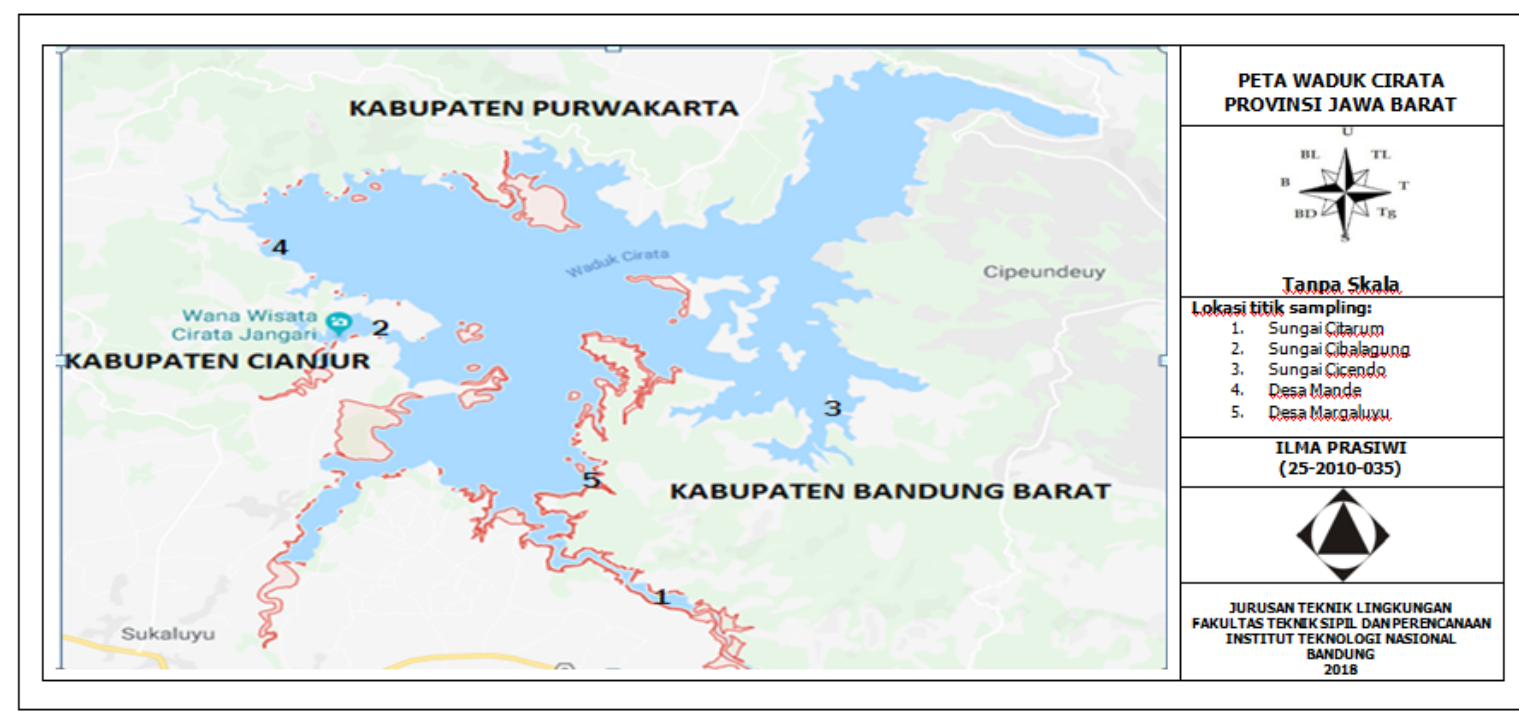

Gambar 1. Peta Waduk Cirata

Sumber: google earth, 2018

\subsection{Metode Pengambilan Sampel}

\section{Sampel Air di 5 Titik Sampling}

Pengambilan sampel air di 2 titik sampling yaitu Desa Mande dan Margaluyu dilakukan berdasarkan 3 kedalaman yaitu permukaan, kedalaman 5 meter berdasarkan kedalaman KJA, dan kedalaman 21 dan $36 \mathrm{~m}$ berdasarkan kedalaman dasar waduk daripada masing-masing titik sampling.

Pengambilan sampel air sungai berdasarkan pada SNI 6989.57:2008 tentang metode pengambilan contoh air permukaan, di mana air diambil pada permukaan sungai. Daerah kedalaman perairan lebih dari 30 m, maka berdasarkan SNI 6989.57:2008 tentang pengambilan sampel dilakukan di tiga titik kedalaman yaitu permukaan, $5 \mathrm{~m}$ dan dasar waduk. Penanganan sampel air penting dilakukan agar kandungan pencemar pada sampel air ketika dilakukan pengujian di laboratorium sama dengan 
kandungan polutan sampel air dilapangan. Alat ukur yang digunakan pada penelitian ini adalah $W Q C$ (Water Quality Checker). Parameter yang dianalisis meliputi suhu, $\mathrm{pH}$, kekeruhan dan oksigen terlarut. Alat pengambilan sampel air yang digunakan adalah Vertical Water Sampler dengan volume 4 liter. Volume sampel air yang diambil untuk pemeriksaan kualitas air di laboratorium sebanyak 2 liter.

Wadah contoh air yang digunakan adalah botol Winkler, botol PE, botol gelas dan botol gelas yang sudah disterilisasi. Penanganan contoh air dilakukan dengan penambahan beberapa bahan pengawet untuk mempertahankan konsentrasi analit terhadap beberapa parameter yang akan dilakukan pengujian, sehingga hasil pengujian akan menunjukan nilai sebenarnya sesuai dengan sampel sebenarnya. Metode penanganan contoh air yang dilakukan adalah sebagai berikut: (1) Asam Nitrat $\left(\mathrm{HNO}_{3}\right)$ untuk parameter logam-logam selain merkuri $(\mathrm{Hg})$; (2) Asam Sulfat $\left(\mathrm{H}_{2} \mathrm{SO}_{4}\right)$ untuk parameter $\mathrm{COD}, \mathrm{NH}_{3}, \mathrm{NO}_{3}$, Minyak dan Fenol;(3) Natrium Hidroksida $(\mathrm{NaOH})$ untuk parameter Sianida $\left(\mathrm{CN}^{-}\right.$ );(4) Seng Asetat untuk parameter Sulfida; dan (4) es (pendingin) untuk parameter BOD.

\section{Sampel Plankton dan Benthos}

Metode pengambilan sampel plankton dilakukan di 2 titik di Desa Mande dan Margaluyu dengan melakukan penyaringan sampel air sebanyak 30 liter menjadi $50 \mathrm{ml}$, dengan menggunakan plankton net nomor 25 yang dilengkapi tabung pengumpul plankton berukuran $50 \mathrm{ml}$. Sampel air yang mengandung plankton tersebut dikonsentrasikan ke dalam botol sampel plankton berukuran $1 \mathrm{ml}$ dan diawetkan dengan larutan lugol 1,5-2 ml sampai warna sampel air menjadi kuning. Metode pengambilan sampel bentos (makro invertebrate) dilakukan dengan cara mengambil sampel lumpur/substrat dari permukaan waduk yang menempel di gulma atau bambu ataupun kayu yang terapung. Sampel yang mengandung bentos kemudian disimpan pada wadah dan diawetkan dengan menggunakan larutan formalin 4-10 persen.

\subsection{Metode Analisis Sampel}

\section{Kualitas Air}

Pengujian sampel air sungai dan air Waduk Cirata dilakukan di laboratorium Pusat Penelitian dan Pengembangan Sumber Daya Alam dan Lingkungan (P3SDAL) Universitas Padjadjaran Kota Bandung. Tabel 2 menjabarkan parameter dan metode pengujian kualitas air.

Tabel 2. Parameter dan Metode Pengujian Kualitas Air

\begin{tabular}{llcc}
\hline No & Parameter & Satuan & Metode \\
\hline & FISIKA & & \\
\hline 1 & Padatan Terlarut Total (TDS) & $\mathrm{mg} / \mathrm{L}$ & SNI 06-6989.27-2005 \\
\hline 2 & Padatan Tersuspensi Total (TSS) & $\mathrm{mg} / \mathrm{L}$ & SNI 06-6989.3-2004 \\
\hline & KIMIA & & \\
\hline 1 & $\mathrm{pH}$ & - & SNI 06-6989.11-2004 \\
\hline 2 & Oksigen terlarut (DO) & $\mathrm{mg} / \mathrm{L}$ & SNI 06-6989 14-2004 \\
\hline 3 & Kelindian $\left(\mathrm{HCO}_{3}\right)$ & $\mathrm{mg} / \mathrm{L}$ & SNI 06-2421-1991 \\
\hline 4 & COD & $\mathrm{mg} / \mathrm{L}$ & SNI 6989.72:2009 \\
\hline 5 & BOD & $\mathrm{mg} / \mathrm{L}$ & SNI 6989.72:2009 \\
\hline 6 & Total Fosfat Sebagai P & $\mathrm{mg} / \mathrm{L}$ & APHA 4500 P-D-2012 \\
\hline 7 & Nitrat $\left(\mathrm{NO}_{3}-\mathrm{N}\right)$ & $\mathrm{mg} / \mathrm{L}$ & SNI 6989.79:2011 \\
\hline 8 & Nitrit $\left(\mathrm{NO}_{2}-\mathrm{N}\right)$ & $\mathrm{mg} / \mathrm{L}$ & SNI 06-6989.9-2004 \\
\hline 9 & Klorin $\left.\mathrm{Bebas}_{(\mathrm{Cl}}\right)$ & $\mathrm{mg} / \mathrm{L}$ & Colometri \\
\hline 10 & Sulfida $\left(\mathrm{H}_{2} \mathrm{~S}\right)$ & $\mathrm{mg} / \mathrm{L}$ & SNI 6989.70:2009 \\
\hline
\end{tabular}




\begin{tabular}{clcc}
\hline No & Parameter & Satuan & Metode \\
\hline 11 & Minyak dan Lemak & $\mathrm{mg} / \mathrm{L}$ & SNI 6989.10:2011 \\
\hline 12 & Tembaga $(\mathrm{Cu})$ & $\mathrm{mg} / \mathrm{L}$ & SNI 6989.6:2009 \\
\hline 13 & Seng $(\mathrm{Zn})$ & $\mathrm{mg} / \mathrm{L}$ & SNI 6989.7:2009 \\
\hline 14 & Krom Heksavalen $\left(\mathrm{Cr}^{6+}\right)$ & $\mathrm{mg} / \mathrm{L}$ & SNI 6989.71:2009 \\
\hline 15 & Timbal $(\mathrm{Pb})$ & $\mathrm{mg} / \mathrm{L}$ & SNI 6989.8:2009 \\
\hline 16 & Kadmium $(\mathrm{Cd})$ & $\mathrm{mg} / \mathrm{L}$ & SNI 6989.16:2009 \\
\hline 17 & Air Raksa $(\mathrm{Hg})$ & $\mathrm{mg} / \mathrm{L}$ & SNI 6989.78:2009 \\
\hline 18 & Arsen $(\mathrm{As})$ & $\mathrm{mg} / \mathrm{L}$ & APHA 3114-C-2012 \\
\hline 19 & Selenium $(\mathrm{Se})$ & $\mathrm{mg} / \mathrm{L}$ & APHA 3114-C-2012 \\
\hline 20 & Fenol & $\mathrm{mg} / \mathrm{L}$ & SNI 06-6989.21-2004 \\
\hline 21 & Boron $(\mathrm{B})$ & $\mathrm{mg} / \mathrm{L}$ & US EPA Method No 200.7-2001 \\
\hline 22 & Kalsium $(\mathrm{Ca})$ & $\mathrm{mg} / \mathrm{L}$ & SNI 06-6989 13-2004 \\
\hline 23 & Kobal $(\mathrm{Co})$ & $\mathrm{mg} / \mathrm{L}$ & SNI 6989.68:2009 \\
\hline 24 & Sianida $(\mathrm{CN}-)$ & $\mathrm{mg} / \mathrm{L}$ & SNI 689.77-2011 \\
\hline 25 & Detergen $(\mathrm{MBAS})$ & $\mathrm{mg} / \mathrm{L}$ & SNI 06-6989.51-2005
\end{tabular}

Sumber: PP No 82 Tahun 2011 tentang PKA dan PPA

Hasil analisa parameter kualitas air sungai dan air Waduk Cirata selanjutnya dibandingkan dengan PP No. 82 Tahun 2001 tentang PKA dan PPA kelas II.

\section{Sampel Plankton dan Bentos}

Analisis sampel plankton dan bentos dilakukan di laboratorium, dimana sampel plankton tersebut kemudian dideterminasi dan diidentifikasi dengan menggunakan kaca "Sedgwick-Rafter (S-R) counting cell chamber" di bawah mikroskop binokuler. Jenis dan jumlah plankton dicatat berdasarkan kelompok taksonominya. Sampel bentos dilakukan penyaringan dan penyortiran berdasarkan jenis dengan cara menggunakan alat lup (kaca pembesar), pinset dan mikroskop binokuler.

\subsection{Metode Analisis Data}

\section{Metode Perhitungan Indeks Pencemaran (IP)}

Penilaian status mutu air bertujuan untuk mengetahui kualitas suatu badan air termasuk ke dalam cemar atau tidak. Penentuan status kualitas air dalam kajian ini dilakukan dengan metode indeks pencemar air sesuai Keputusan Menteri Negara Lingkungan Hidup Nomor 115 Tahun 2003 tentang Pedoman Penentuan Status Mutu Air. Rumus yang digunakan dalam perhitungan indeks pencemaran dapat di lihat pada Persamaan 1.

$\mathbf{P} \mathbf{I}_{\mathbf{j}}=\sqrt{\frac{\left(\mathrm{C}_{\mathrm{i}} / \mathrm{L}_{\mathrm{ij}}\right)_{\mathrm{M}}^{2}+\left(\mathrm{C}_{\mathrm{i}} / \mathrm{L}_{\mathrm{ij}}\right)_{\mathrm{R}}^{2}}{2}}$

dimana:

$\mathrm{Lij}=$ konsentrasi parameter kualitas air yang dicantumkan dalam baku mutu suatu peruntukan air (j); $\mathrm{Ci}=$ konsentrasi parameter kualitas air hasil pengukuran; $\mathrm{Pij}=$ Indeks Pencemaran bagi peruntukan (Tabel 3); (Ci/Lij)M = Nilai Ci/Lij maksimum; $(\mathrm{Ci} / \mathrm{Lij}) \mathrm{R}=$ Nilai Ci/Lij rata-rata. 
Tabel 3. Evaluasi Terhadap Nilai Indeks Pencemar

\begin{tabular}{cc}
\hline Nilai IP & Status Air \\
\hline $0 \leq \mathrm{PI}_{\mathrm{j}} \leq 1,0$ & Memenuhi baku mutu (kondisi baik) \\
\hline $1,0<\mathrm{PI}_{\mathrm{j}} \leq 5,0$ & Cemar ringan \\
\hline $5,0<\mathrm{PI}_{\mathrm{j}} \leq 10$ & Cemar sedang \\
\hline $\mathrm{PI}_{\mathrm{j}}>10$ & Cemar berat \\
\hline
\end{tabular}

Sumber: KEPMENLH No.115 Tahun 2003

\section{Metode Perhitungan Indeks Keanekaragaman}

Metode yang digunakan untuk menganalisis data biota air plankton dan bentos dengan cara menghitung nilai indeks keanekaragaman jenis menurut persamaan Shannon-Wiener. Nilai indeks keanekaragaman dapat dihitung menggunakan Persamaan 2.

$\mathbf{H}^{\prime} \quad=-\sum \frac{\mathrm{ni}}{\mathrm{N}} \ln \frac{\mathrm{ni}}{\mathrm{N}}$

dimana:

$\mathrm{H}^{\prime}$ = indeks diversitas Shannon-Weinner; $\mathrm{ni}=$ Jumlah total individu dari masing-masing jenis; $\mathrm{N}=$ Jumlah total individu seluruh jenis.

Kriteria derajat pencemaran berdasarkan metode indeks keanekaragaman menurut Shannon \& Wiener disajikan pada Tabel 4.

Tabel 4. Kriteria Pencemaran Indeks Shannon\&Wiener

\begin{tabular}{lc}
\multicolumn{1}{c}{$\begin{array}{c}\text { Derajat } \\
\text { Pencemaran }\end{array}$} & $\begin{array}{c}\text { Indeks Diversitas } \\
\text { (Keanekaragaman) }\end{array}$ \\
\hline Komunitas biota tidak stabil (kualitas air tercemar berat) & $\mathrm{H}^{\prime}<1$ \\
\hline Stabilitas komunitas biota sedang (kualitas air tercemar sedang) & $1<\mathrm{H}^{\prime}<3$ \\
\hline Stabilitas komunitas biota dalam kondisi prima atau stabil (kualitas air bersih) & $\mathrm{H}^{\prime}>3$ \\
\hline Sumber: Basmi, 1999 &
\end{tabular}

\section{HASIL DAN PEMBAHASAN}

\subsection{Analisis Kualitas Air Sungai yang Masuk Ke Waduk Cirata}

Parameter yang diuji sebanyak 27 parameter yang terdiri dari 2 parameter Fisika, 25 parameter Kimia. Seluruh kualitas air yang dipantau dibandingkan dengan baku mutu berdasarkan PP No. 82 Tahun 2001 tentang PKA dan PPA kelas II. Berdasarkan hasil pengukuran jumlah parameter kualitas air yang tidak memenuhi baku mutu di 3 sungai sebanyak 6 parameter. Jenis parameter yang melebihi baku mutu di sungai adalah BOD, Nitrit, Klorin Bebas, Timbal dan Fenol. Terkait parameter yang melebihi baku mutu lebih jelasnya dapat melihat uraian di bawah ini.

Berdasarkan hasil pengukuran nilai DO di 3 titik sampling, Sungai Cibalagung dan Cicendo tidak memenuhi baku mutu yang dipersyaratakan dalam PP No. 82 Tahun 2001 tentang PKA dan PPA untuk kelas II sebesar $4 \mathrm{mg} / \mathrm{L}$. Nilai masing-masing parameter DO di lokasi tersebut sebesar 3,5 mg/L dan 3,3 mg/L, untuk Sungai Citarum hasilnya memenuhi baku mutu. Tingginya kadar oksigen terlarut di Sungai Citarum dibandingkan Sungai Cibalagung dan Cicendo dapat disebabkan salah satunya oleh pergerakan (turbulence) akibat derasnya aliran arus air. Kandungan oksigen terlarut dalam perairan 
juga berfluktuasi secara harian (diurnal) dan musimam, tergantung pada percampuran (mixing) dan pergerakan (turbulence) massa air, aktivitas fotosintesis, respirasi, dan limbah (effluent) yang masuk ke badan air (Effendi, 2003). Konsentrasi DO di titik lokasi sampling sungai disajikan pada Gambar 2.

Berdasarkan hasil pengukuran nilai BOD di 3 titik sampling, Sungai Citarum dan Cibalagung tidak memenuhi baku mutu yang dipersyaratakan dalam PP No. 82 Tahun 2001 tentang PKA dan PPA kelas II sebesar $3 \mathrm{mg} / \mathrm{L}$. Nilai masing-masing parameter BOD di lokasi tersebut sebesar 6,47 mg/L dan 4,95 $\mathrm{mg} / \mathrm{L}$, untuk Sungai Cicendo hasilnya memenuhi baku mutu. Tingginya kadar BOD di Sungai Citarum dan Cibalagung disebabkan adanya pencemaran yang terjadi di sekitar perairan tersebut, di mana Sungai Citarum dan Cibalagung merupakan perairan yang lingkungan sekitarnya memiliki berbagai macam aktivitas seperti pemukiman padat penduduk serta terdapat industri-industri yang limbah domestik maupun non-dometik dibuang ke sungai secara langsung tanpa adanya pengolahan sehingga mengakibatkan kadar BOD melebihi baku mutu. Kadar BOD di Sungai Cicendo lebih rendah dibandingkan kedua sungai lainnya, di mana Sungai Cicendo merupakan sungai yang alirannya berdekatan dengan TPA Sarimukti. Hal ini menunjukkan bahwa adanya keberadaan TPA Sarimukti tidak mempengaruhi kualitas sungai tersebut. Nilai BOD suatu perairan dapat dikatakan baik apabila nilai BOD memenuhi baku mutu yang diperbolehkan. Jika nilai BOD suatu perairan yang melebihi baku mutu maka dapat dikatakan telah terjadi pencemaran. Semakin tinggi nilai BOD maka semakin banyak oksigen yang dibutuhkan oleh bakteri untuk mengurai zat-zat organik dalam perairan (Davis and Cornwell, 1991). Konsentrasi BOD di titik lokasi sampling sungai disajikan pada Gambar 3.

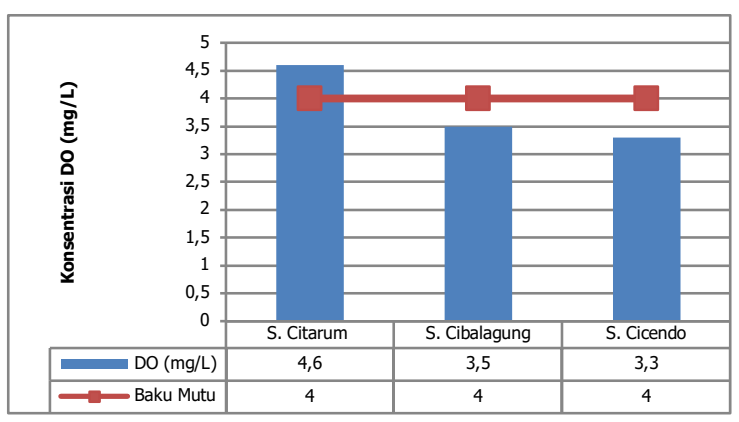

Gambar 2. Konsentrasi DO

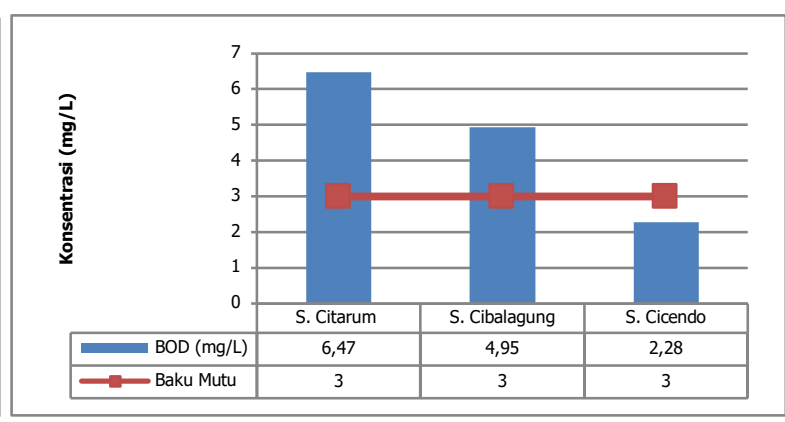

Gambar 3. Konsentrasi BOD

Berdasarkan hasil pengukuran nilai Nitrit di 3 titik sampling, hanya Sungai Citarum yang tidak memenuhi baku mutu yang disyaratakan dalam PP No. 82 Tahun 2001 tentang PKA dan PPA kelas II sebesar 0,06 mg/L. Nilai parameter Nitrit di lokasi tersebut sebesar 0,208 mg/L, sedangkan di Sungai Cibalagung dan Cicendo hasilnya memenuhi baku mutu. Penyebab tingginya kadar Nitrit di Sungai Citarum tidak terlepas dari sumber limbah industri dan limbah domestik yang membuang limbahnya secara langsung ke badan sungai tanpa adanya pengolahan terlebih dahulu dan disebabkan oleh masukan beban pencemar dari anak sungai yang alirannya masuk ke DAS Citarum. Kadar nitrit pada perairan relatif kecil karena nitrit dalam air segera dioksidasi menjadi nitrat. Perairan alami mengandung nitrit sekitar $0,001 \mathrm{mg} /$ liter dan sebaiknya tidak melebihi $0,06 \mathrm{mg} / \mathrm{liter}$ (Canadian Council of Resource and Environmental Minister, 1987). Kadar nitrit yang melebihi 0,05 mg/liter dapat bersifat toksik bagi organisme perairan yang sangat sensitif (Moore, 1991). Konsentrasi Nitrit di titik lokasi sampling sungai disajikan pada Gambar 4. 
Berdasarkan hasil pengukuran nilai Klorin bebas di 3 titik sampling, semua sungai tidak memenuhi baku mutu yang disyaratakan dalam PP No. 82 Tahun 2001 tentang PKA dan PPA kelas II sebesar $0,03 \mathrm{mg} / \mathrm{L}$. Nilai masing-masing parameter klorin bebas di lokasi tersebut sebesar 10,3 mg/L, 2,7 $\mathrm{mg} / \mathrm{L}$, dan $0,54 \mathrm{mg} / \mathrm{L}$. Secara alami, klorin terdapat dalam bentuk ion klorida dengan jumlah relatif jauh lebih besar dibandingkan ion-ion halogen lainnya. Kadar klorin yang tinggi disebabkan oleh banyaknya limbah organik yang dibuang secara langsung ke perairan, hal ini akan berdampak pada lingkungan seperti menyebabkan air kekurangan kadar oksigen terlarut. Klorin dianggap sebagai senyawa yang beracun dan berbahaya bagi biota perairan terutama derivatnya seperti asam hipoklorin dan Kloramin. Klorin biasanya sering digunakan sebagai desinfektan untuk menghilangkan mikroorganisme yang tidak dibutuhkan, terutama bagi air yang diperuntukan untuk kepentingan domestik dan juga terkadang digunakan dalam berbagai indutri seperti klorin dalam bentuk asam klorida $(\mathrm{HCl})$ dapat digunakan pada industri logam sebagai bahan baku ektraksi. Konsentrasi Klorin Bebas di titik lokasi sampling sungai disajikan pada Gambar 5.

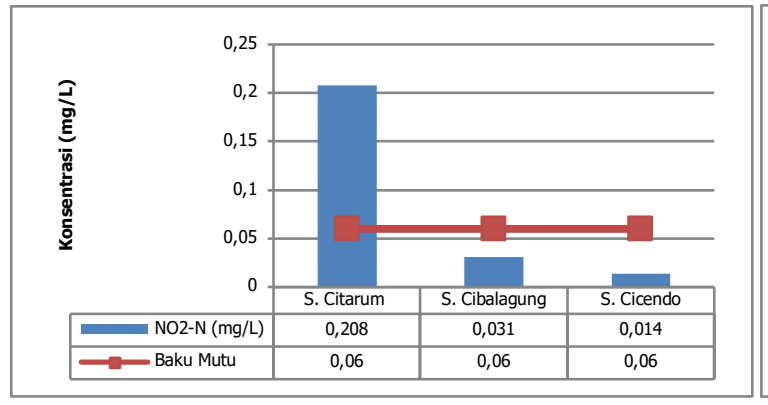

Gambar 4. Konsentrasi Nitrit Gambar

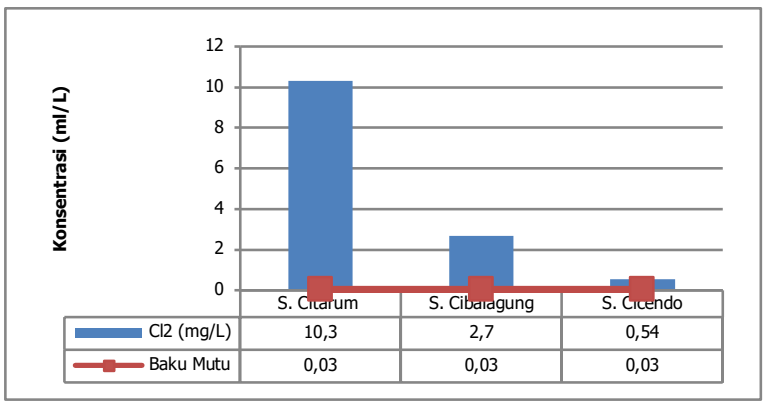

5. Konsentrasi Klorin Bebas

Berdasarkan hasil pengukuran nilai Timbal di 3 titik sampling, hanya di Sungai Citarum dan Cibalagung yang tidak memenuhi baku mutu yang disyaratakan dalam PP No. 82 Tahun 2001 tentang PKA dan PPA kelas II sebesar $0,03 \mathrm{mg} / \mathrm{L}$. Nilai masing-masing parameter Timbal di lokasi tersebut sebesar $0,050 \mathrm{mg} / \mathrm{L}$, dan $0,034 \mathrm{mg} / \mathrm{L}$. Kadar timbal yang tinggi dalam perairan disebabkan oleh limbah industri dan limbah domestik yang dibuang ke badan air atau sungai secara langsung tanpa adanya pengolahan terlebih dahulu. Namun, kadar timbal dalam perairan biasanya relatif kecil karena tingkat kelarutannya rendah. Kadar timbal pada perairan tawar alami biasanya yaitu $<0,05 \mathrm{mg} /$ liter (Moore, 1991). Konsentrasi Timbal di titik lokasi sampling disajikan pada Gambar 6.

Berdasarkan hasil pengukuran nilai Fenol di 3 titik sampling, hanya di Sungai Citarum dan Cicendo yang tidak memenuhi baku mutu yang disyaratakan dalam PP No. 82 Tahun 2001 tentang PKA dan PPA kelas II sebesar $0,001 \mathrm{mg} / \mathrm{L}$. Nilai masing-masing parameter Fenol di 2 sungai yaitu sama sebesar $0,005 \mathrm{mg} / \mathrm{L}$. Penyebab kadar fenol tinggi dalam perairan dapat berupa limbah industri dan limbah domestik. Senyawa fenol ditemukan dari proses pemurnian minyak, industri kimia, tekstil, plastik, dan lain-lain. Dampak adanya keberadaan fenol di perairan dengan kadar lebih dari 0,01 mg/liter bersifat toksik bagi ikan (UNESCO/WHO/UNEP, 1992). Konsentrasi Fenol di titik lokasi sampling sungai disajikan pada Gambar 7. 


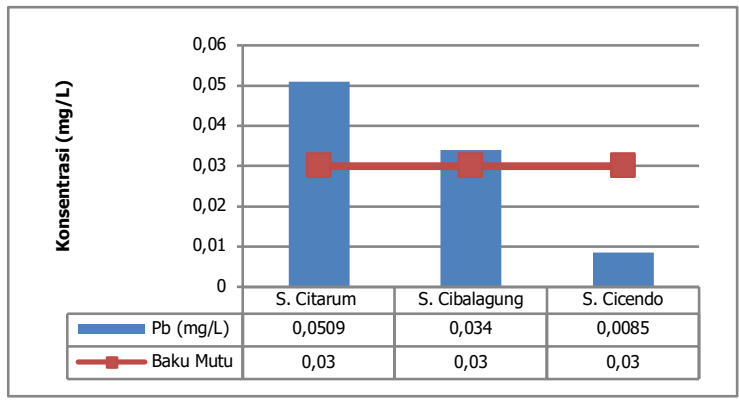

Gambar 6. Konsentrasi Timbal (Pb)

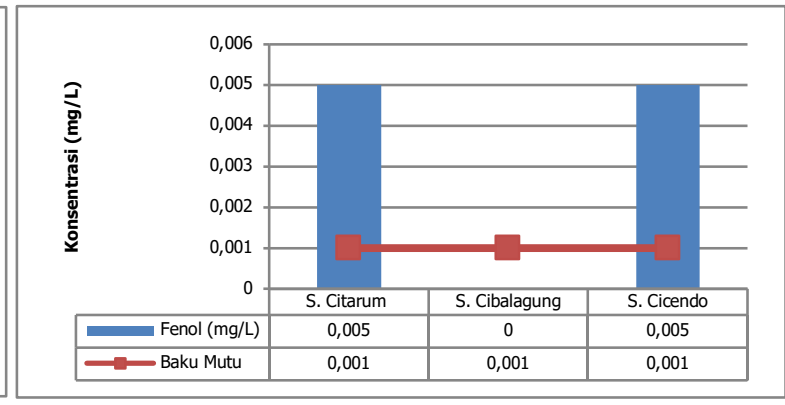

Gambar 7. Konsentrasi Fenol

Indeks pencemaran merupakan salah satu metode yang digunakan untuk menetukan status mutu air suatu sumber air. Status mutu air menunujukan tingkat kondisi mutu sumber air dalam kondisi cemar atau kondisi baik dengan membandingkan dengan baku mutu yang telah ditetapkan. Hasil Perhitungan indeks pencemaran di 3 sungai disajikan pada Tabel 5.

Tabel 5. Status Mutu Sungai

\begin{tabular}{lcl}
\hline \multicolumn{1}{c}{ Sungai } & Nilai Indeks Pencemar (IP) & Status \\
\hline Citarum & 9,75 & Cemar Sedang \\
\hline Cibalagung & 7,74 & Cemar Sedang \\
\hline Cicendo & 7,92 & Cemar Sedang \\
\hline
\end{tabular}

Sumber: Hasil Perhitungan Indeks Pencemar (IP), 2018

Berdasarkan Tabel 5 dapat dilihat bahwa nilai Indeks Pencemaran pada Sungai Citarum cenderung lebih besar dibandingkan Sungai Cibalagung dan Cicendo. Keadaan ini menunjukan besarnya masukan beban pencemar yang masuk ke Sungai Citarum sehingga tingkat beban pencemaran lebih besar. Berdasarkan KepMenLH No. 115 Tahun 2003 tentang pedoman penentuan status mutu air, nilai indeks pencemaran yang berada pada kisaran $5,0<\mathrm{PIj} \leq 10$ maka dikategorikan cemar sedang. Berdasarkan hal tersebut Sungai Citarum, Cibalagung dan Cicendo dikategorikan sebagai sungai dengan status mutu cemar sedang.

\subsection{Analisis Kualitas Air di Daerah Perairan Waduk Cirata}

Parameter yang diuji sebanyak 27 parameter yang terdiri dari 2 parameter Fisika, 25 parameter Kimia. Seluruh kualitas air yang dipantau dibandingkan dengan baku mutu berdasarkan PP No. 82 Tahun 2001 tentang PKA dan PPA untuk kelas II. Hasil pengukuran jumlah parameter kualiatas air yang tidak memenuhi baku mutu di 2 titik sampling perairan waduk dengan kedalaman berbeda sebanyak 5 parameter. Jenis parameter yang melebihi baku mutu di perairan waduk adalah DO, BOD, Klorin Bebas, Timbal dan Fenol. Terkait parameter yang melebihi baku mutu lebih jelasnya dapat melihat uraian di bawah ini.

Berdasarkan hasil pengukuran nilai DO di 2 titik sampling perairan Waduk Cirata dengan kedalaman yang berbeda-beda, nilai DO yang dikatagorikan buruk atau rendah sesuai baku mutu yang disyaratakan dalam PP No. 82 Tahun 2001 tentang PKA dan PPA kelas II sebesar $<4$ mg/L di Desa Mande (kedalaman $5 \mathrm{~m}$ dan $21 \mathrm{~m}$ ) dan Margaluyu (kedalaman $5 \mathrm{~m}$ dan $36 \mathrm{~m}$ ). Kondisi kedalaman mempengaruhi nilai DO yang ada di daerah perairan Waduk Cirata, semakin ke dekat dasar maka nilai DO nya akan semakin kecil. Konsentrasi DO di titik lokasi sampling perairan disajikan pada Gambar 8. 
Berdasarkan hasil pengukuran nilai BOD di 2 titik sampling perairan di Waduk Cirata dengan kedalaman yang berbeda hanya di titik Desa Margaluyu pada kedalaman $36 \mathrm{~m}$ yang memenuhi baku mutu, untuk titik yang lainnya melebihi baku mutu yang dipersyaratkan dalam PP No. 82 Tahun 2001 tentang PKA dan PPA untuk kelas II sebesar $3 \mathrm{mg} / \mathrm{L}$. Konsentrasi BOD di titik lokasi sampling genengan disajikan pada Gambar 9.

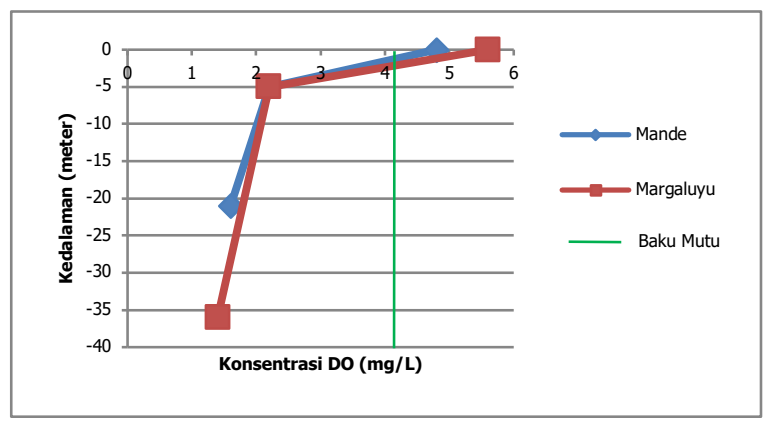

Gambar 8. Konsentrasi DO

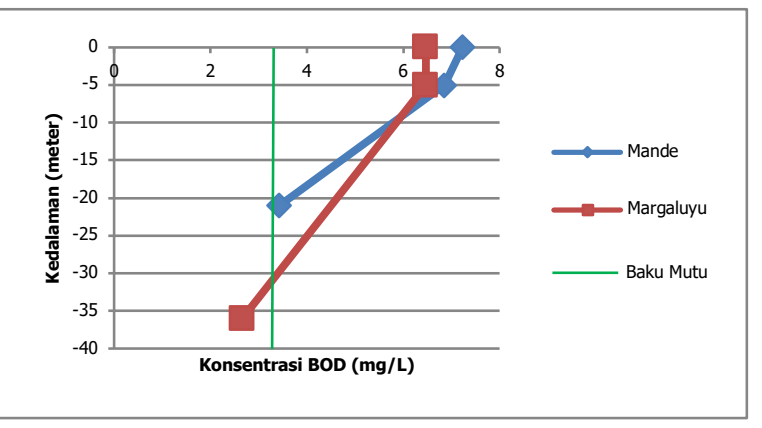

Gambar 9. Konsentrasi BOD

Berdasarkan hasil pengukuran nilai Klorin bebas di 2 titik perairan di Waduk Cirata dengan kedalaman yang berbeda hanya di titik Desa Mande pada kedalaman $5 \mathrm{~m}$ dan Margaluyu pada kedalaman $5 \mathrm{~m}$ dan 36 m yang tidak memenuhi baku mutu, yang dipersyaratkan dalam PP No. 82 Tahun 2001 tentang Pengelolaan PKA dan PPA untuk kelas II sebesar 0,03 mg/L. Konsentrasi Klorin Bebas di titik lokasi sampling genengan disajikan pada Gambar 10.

Berdasarkan hasil pengukuran nilai parameter Timbal di 2 titik sampling perairan Waduk Ciarta dengan kedalaman yang berbeda hanya di Desa Margaluyu pada permukaan perairan waduk yang memenuhi baku mutu, selain titik sampling itu yang lainnya melebihi baku mutu yang dipersyaratkan dalam PP No. 82 Tahun 2001 tentang PKA dan PPA untuk kelas II sebesar 0,03 mg/L. Konsentrasi Timbal di titik lokasi sampling genangan disajikan pada Gambar 11.

Berdasarkan hasil pengukuran nilai Fenol di 2 titik perairan Waduk Cirata dengan kedalaman berbeda hanya di titik Desa Mande pada kedalaman $21 \mathrm{~m}$ dan Margaluyu pada kedalaman $36 \mathrm{~m}$ yang melebihi baku mutu, yang dipersyaratkan dalam PP No. 82 Tahun 2001 tentang PKA dan PPA kelas II sebesar 0,001 mg/L. Konsentrasi Fenol di titik lokasi sampling genengan disajikan pada Gambar 12.

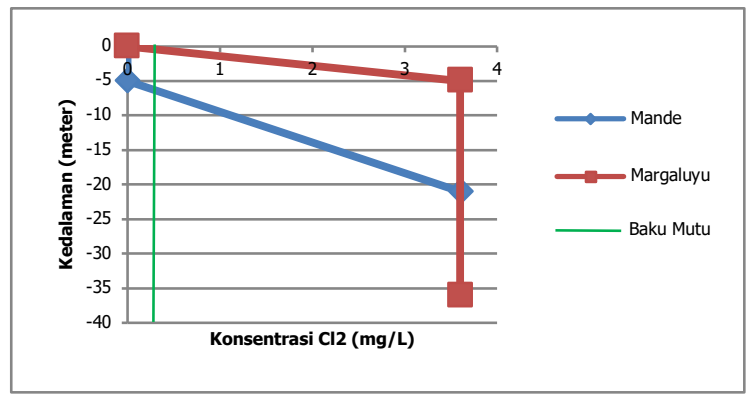

Gambar 10. Konsentrasi $\mathrm{Cl}_{2}$

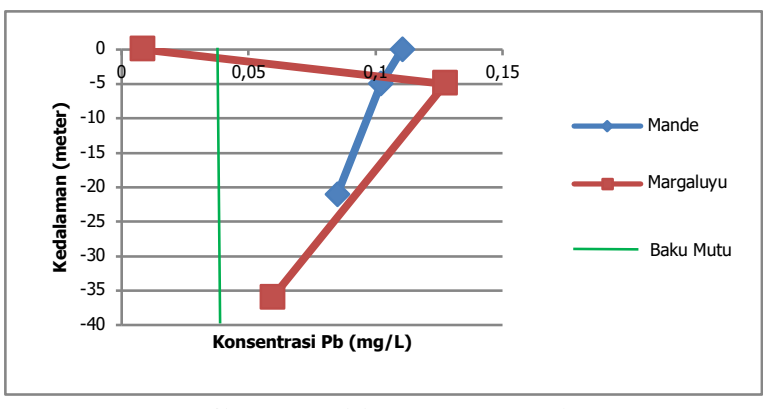

Gambar 11. Konsentrasi Pb 


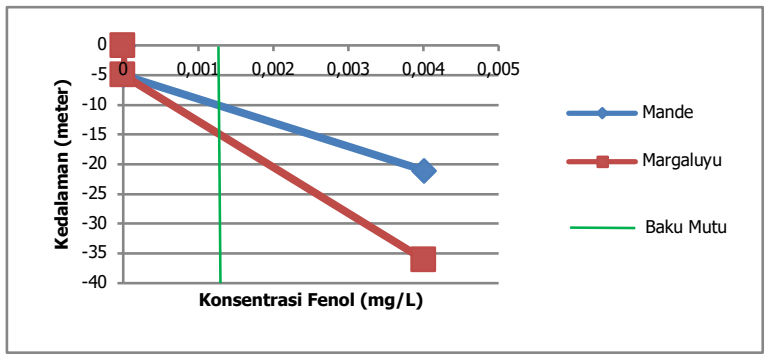

Gambar 12. Konsentrasi Fenol (mg/L)

Indeks pencemaran merupakan salah satu metode yang digunakan untuk menetukan status mutu air suatu sumber air. Status mutu air menunujukan tingkat kondisi mutu sumber air dalam kondisi cemar atau kondisi baik dengan membandingkan dengan baku mutu yang telah ditetapkan. Hasil Perhitungan indeks pencemaran di 2 titik perairan Waduk Cirata disajikan pada Tabel 6.

Tabel 6. Status Mutu Perairan Waduk Cirata berdasarkan Kedalaman

\begin{tabular}{|c|c|c|}
\hline Titik Sampling & Nilai Indeks Pencemar (IP) & Status \\
\hline \multicolumn{3}{|l|}{ Mande } \\
\hline - $\quad$ Permukaan & 7,80 & Cemar sedang \\
\hline - $\quad$ Kedalaman $5 \mathrm{~m}$ & 7,88 & Cemar sedang \\
\hline - $\quad$ Kedalaman $21 \mathrm{~m}$ & 8,37 & Cemar sedang \\
\hline \multicolumn{3}{|l|}{ Margaluyu } \\
\hline - $\quad$ Permukaan & 7,83 & Cemar sedang \\
\hline - $\quad$ Kedalaman $5 \mathrm{~m}$ & 7,92 & Cemar sedang \\
\hline - $\quad$ Kedalaman $36 \mathrm{~m}$ & 9,07 & Cemar sedang \\
\hline
\end{tabular}

Sumber: Hasil Perhitungan Indeks Pencemar (IP), 2018

Berdasarkan Tabel 6 dapat disimpulkan bahwa semakin dalam mutu air semakin buruk. Terlihat dari nilai indeks pencemaran di Desa Mande dan Margaluyu pada kedalaman 21 dan $36 \mathrm{~m}$ cenderung lebih besar dibandingkan dengan di permukaan waduk dan pada kedalaman $5 \mathrm{~m}$. Keadaan ini menunjukan semakin dalam bahan organik lebih sulit untuk diurai oleh bakteri karena semakin kecilnya oksigen dan adanya proses fotosintesis di permukaan. Berdasarkan KepMenLH No. 115 Tahun 2003 tentang Pedoman Penentuan Status Mutu Air, nilai indeks pencemaran yang berada pada kisaran $5,0<\mathrm{PIj} \leq 10$ maka dikategorikan cemar sedang. Maka perairan Waduk Cirata pada titik sampling Desa Mande dan Margaluyu dikategorikan sebagai perairan dengan status mutu cemar sedang.

\subsection{Indeks Keanekaragaman}

Indeks keanekaragaman digunakan dalam menentukan tingkat keanekaragaman jenis plankton dan bentos yang hidup di perairan Waduk Cirata dengan tingkat pencemaran yang terjadi di perairan waduk tersebut. Tabel 7, Tabel 8 dan Tabel 9 menjabarkan jenis keanekaragaman dan jumlah plankton dan bentos.

Tabel 7. Hasil Analisis Fitoplankton Berdasarkan Metode Indeks Shanon\&Wieneer

\begin{tabular}{clcccccc}
\hline \multirow{2}{*}{ NO } & \multirow{2}{*}{ ORGANISME } & \multirow{2}{*}{} & \multicolumn{2}{c}{ STASIUN } & & & \multicolumn{2}{c}{ STASIUN } \\
\cline { 3 - 4 } \cline { 7 - 9 } & & Mande & Margaluyu & NO & ORGANISME & Mande & Margaluyu \\
\hline 1 & Caetophora sp. & - & 33 & 10 & Nitzschia sp. & 132 & 66 \\
\hline 2 & Camaesiphon $\mathrm{sp}$. & 33 & - & 11 & Oscillatoria ceae. & 297 & 165 \\
\hline 3 & Cladophora $\mathrm{sp}$. & 33 & - & 12 & Peridinium sp. & 66 & - \\
\hline
\end{tabular}




\begin{tabular}{|c|c|c|c|c|c|c|c|}
\hline \multirow{2}{*}{ NO } & \multirow{2}{*}{ ORGANISME } & \multicolumn{2}{|c|}{ STASIUN } & \multirow[b]{2}{*}{ NO } & \multirow[b]{2}{*}{ ORGANISME } & \multicolumn{2}{|c|}{ STASIUN } \\
\hline & & Mande & Margaluyu & & & Mande & Margaluyu \\
\hline 4 & Cymbella sp. & 33 & - & 13 & $\begin{array}{l}\text { Planktolyngbya } \\
\text { sp. }\end{array}$ & 33 & - \\
\hline 5 & Diatom sp. & 561 & 693 & 14 & Spirogyra sp. & 132 & 99 \\
\hline 6 & Gomphonema sp. & 66 & - & 15 & Synedra sp. & 429 & - \\
\hline 7 & Lemanea sp. & - & 33 & 16 & $\begin{array}{l}\text { Tabellaria } \\
\text { flocculosa. }\end{array}$ & 33 & - \\
\hline 8 & Microcytis sp. & 33 & - & 17 & Tribonema sp. & 957 & 132 \\
\hline 9 & Naviculla sp. & - & 33 & 18 & Volvox sp. & $8.250^{*}$ & $4.620^{*}$ \\
\hline \multicolumn{6}{|c|}{ JUMLAH } & 11.088 & 5.874 \\
\hline \multicolumn{6}{|c|}{ I.D.SHANON\&WIENER } & 1,076 & $\mathbf{0 , 8 3 3}$ \\
\hline
\end{tabular}

Sumber: Hasil Analisa Laboratorium, 2017

Keterangan: *) Spesies dominan.

Tabel 8. Hasil Analisis Zooplankton Berdasarkan Metode Indeks Shanon\&Wieneer

\begin{tabular}{|c|c|c|c|c|c|c|c|}
\hline \multirow{2}{*}{ NO } & \multirow{2}{*}{ ORGANISME } & \multicolumn{2}{|c|}{ STASIUN } & \multirow{2}{*}{ NO } & \multirow{2}{*}{ ORGANISME } & \multicolumn{2}{|c|}{ STASIUN } \\
\hline & & Mande & Margaluyu & & & Mande & Margaluyu \\
\hline 1 & $\begin{array}{l}\text { Brachionus } \\
\text { bidentata. }\end{array}$ & 165 & - & 10 & Keratella sp. & 1.287 & - \\
\hline 2 & $\begin{array}{l}\text { Brachionus } \\
\text { calyciflorus. }\end{array}$ & $10.560 *$ & 528 & 11 & Lecane sp. & 33 & - \\
\hline 3 & $\begin{array}{l}\text { Brachionus } \\
\text { facaltis. }\end{array}$ & 891 & 231 & 12 & Moina sp. & 330 & $2.310^{*}$ \\
\hline 4 & Brachionus sp. & 66 & 33 & 13 & Moinodaphnia sp. & 99 & 33 \\
\hline 5 & Chidorus sp. & 33 & - & 14 & Nauplii sp. & 33 & - \\
\hline 6 & Cyclop sp. & 726 & 528 & 15 & Notholca sp. & - & 33 \\
\hline 7 & Cyprya sp. & 33 & - & 16 & Polyartha sp. & 198 & 99 \\
\hline 8 & Epystylis sp. & 99 & 33 & 17 & Tricocerca sp. & - & 99 \\
\hline 9 & Filinia sp. & 33 & - & & & & \\
\hline \multicolumn{6}{|c|}{ JUMLAH } & 14.586 & 3.927 \\
\hline \multicolumn{6}{|c|}{ I.D.SHANON\&WIENER } & 1,124 & 1,365 \\
\hline
\end{tabular}

Sumber: Hasil Analisa Laboratorium, 2017 Keterangan: *) Spesies dominan.

Berdasarkan Tabel 7 dan Tabel 8 nilai total plankton dari fitoplankton dan zooplankton di Desa Mande dan Margaluyu sebesar 25.674 dan 9.801 dengan nilai indeks keanekaragaman sebesar 1,787 dan 1,179. Jumlah fitoplankton pada titik sampling Desa Mande dan Margaluyu sebanyak 15 dan 9 spesies dengan nilai indeks keanekaragaman fitoplankton sebesar 1,076 da 0,833. Spesies yang mendominasi perairan tersebut adalah Volvox sp. Spesies ini merupakan salah satu spesies ganggang hijau berbentuk koloni menyerupai bola yang hidup di air tawar dan mampu melindungi dirinya dari zat-zat beracun yang berada di perairan. Oleh karena itu, genus-genus tersebut mampu hidup pada perairan yang mengalami pencemaran (Jhon dkk, 2002).

Berdasarkan Tabel 8 dapat dilihat jenis zooplankton pada titik sampling Desa Mande dan Margaluyu sebanyak 15 dan 10 spesies dengan nilai indeks keanekaragaman zooplankton sebesar 1,124 dan 1,365. Spesies yang mendominasi perairan Waduk Cirata adalah Brachionus calyciflorus dan Moina $s p$. Brachionus calyciflorus adalah spesies rotifera planktonik kecil hewan air tawar. Moina sp merupakan zooplankton air tawar yang hidup di sungai, parit, rawa-rawa dan air tergenang. Zooplankton ini tersebar luas yang disebabkan oleh aliran air dan terbawa binatang lainnya. Hal ini di 
mungkinkan karena telur Moina sp. tersebut mampu bertahan pada kondisi perairan yang sangat buruk, bahkan perairan yang sedikit berair. Apabila kondisi perairan telah memenuhi persyaratan untuk kehidupannya, maka telur-telur tersebut akan menetas (John dkk, 2002). Lingkungan yang mendukung pertumbuhan Moina $s p$. adalah pada kisaran suhu $22-31^{\circ} \mathrm{C}$ dan $\mathrm{pH}$ antara 6,6-7,4.

Berdasarkan hasil analisis di atas dapat disimpulkan bahwa plankton dapat digunakan sebagai indikator untuk mengetahui status suatu perairan. Dari 15 dan 9 jenis total fitoplankton di Mande dan Margaluyu, Volvox sp. mendominasi perairan Waduk Cirata yaitu di Desa Mande sebanyak 8.250 dari total fitoplankton sebanyak 11.088 dan di Margaluyu sebanyak 4.620 dari total phytoplankton sebanyak 5.874. Keadaan ini menunjukkan bahwa perairan Waduk Cirata telah terjadi pencemaran, dimana keanekaragaman fitoplankton yang hidup di perairan Waduk Cirata tidak tersebar merata sehingga hanya spesies Volvox $s p$. yang dapat bertahan hidup di perairan tersebut. Hal ini sesuai dengan konsisi perairan Waduk Cirata di Desa Mande dan Margaluyu dikategorikan dalam perairan cemar sedang berdasarkan nilai indeks pencemaran. Dari 15 dan 10 jenis total zooplankton di Desa Mande dan Margaluyu, spesies yang mendominasi perairan Waduk Cirata yaitu di Mande Brachionus calyciflorus sebanyak 10.560 dari total zooplankton sebanyak 14.586 dan di Margaluyu Moina sp. sebanyak 2.310 dari total zooplankton sebanyak 3.927. Keadaan ini menunjukkan bahwa perairan Waduk Cirata telah terjadi pencemaran, dimana keanekaragaman zooplankton yang hidup di perairan Waduk Cirata tidak tersebar merata sehingga hanya spesies Brachionus calyciflorus dan Moina sp. yang dapat bertahan hidup di perairan tersebut. Hal ini sesuai dengan konsisi perairan Waduk Cirata di Desa Mande dan Margaluyu dikategorikan dalam perairan cemar sedang berdasarkan nilai indeks pencemaran.

Tabel 9. Hasil Analisis Bentos Berdasarkan Metode Indeks Shanon\&Wieneer

\begin{tabular}{|c|c|c|c|c|c|c|c|}
\hline \multirow{2}{*}{ NO } & \multirow{2}{*}{ ORGANISME } & \multicolumn{2}{|c|}{ STASIUN } & \multirow{2}{*}{ NO } & \multirow{2}{*}{ ORGANISME } & \multicolumn{2}{|c|}{ STASIUN } \\
\hline & & Mande & Margaluyu & & & Mande & Margaluyu \\
\hline 1 & Enallagma sp. & 2 & 4 & 6 & $\begin{array}{l}\text { Macrobrachium } \\
\text { sp. }\end{array}$ & 10 & $16^{*}$ \\
\hline 2 & Filopaludina sp. & $16^{*}$ & - & 7 & Physastra sp. & 6 & 10 \\
\hline 3 & Gomphidae. & 2 & - & 8 & Pomacea sp. & 2 & 2 \\
\hline 4 & Libellula sp. & - & 4 & 9 & Renatra sp. & 6 & - \\
\hline 5 & Lymnaea sp. & 2 & 2 & & & & \\
\hline \multicolumn{6}{|c|}{ JUMLAH } & 46 & 38 \\
\hline \multicolumn{6}{|c|}{ I.D.SHANON\&WIENER } & 1,776 & 1,499 \\
\hline
\end{tabular}

Sumber: Hasil Analisa Laboratorium, 2017 Keterangan: *) Spesies dominan.

Berdasarkan Tabel 10 dapat dilihat jenis bentos pada titik sampling Desa Mande dan Margaluyu di perairan Waduk Cirata sebanyak 8 dan 6 spesies dengan nilai total indeks keanekaragaman bentos sebesar 1,776 dan 1,499. Spesies yang mendominasi perairan tersebut adalah Filopaludina sp. dan Macrobrachium sp. Filopaludina sp. merupakan spesies keong tutut yang hidup di air tawar. Macrobrachium sp. merupakan spesies udang yang dapat hidup di sungai dan air tawar lainnya. Beberapa sifat hidup hewan bentos ini memberikan keuntungan untuk digunakan sebagai indikator biologi diantaranya mempunyai habitat relatif menetap. Dengan demikian, perubahan kualitas air tempat hidupnya akan berpengaruh terhadap komposisi dan kelimpahannya. Komposisi/ kelimpahan makrozoobentos bergantung kepada toleransi ataupun sensitifitasnya terhadap perubahan lingkungan (Guntur, 1993). 
Tabel 10. Status Mutu Perairan Waduk Cirata Berdasarkan Kriteria Shannon\&Wiener

\begin{tabular}{lcclc}
\hline \multirow{2}{*}{ Jenis } & \multicolumn{2}{c}{ Nilasi } & \multicolumn{2}{c}{ Derajat Pencemaran } \\
\cline { 2 - 5 } & Desa Mande & Desa Margaluyu & Desa Mande & Desa Margaluyu \\
\hline Total Plankton & 1,787 & 1,179 & Cemar sedang & Cemar sedang \\
\hline Benthos & 1,776 & 1,499 & Cemar sedang & Cemar sedang \\
\hline
\end{tabular}

Sumber: Hasil Analisa, 2018

Berdasarkan hasil perhitungan nilai indeks keanekaragaman total plankton dan bentos yang diukur dengan kriteria pencemaran menurut Shannon\&Wiener, nilai indeks diversitas (keanekargaman) plankton dan bentos pada titik sampling di Desa Mande dan Margaluyu berkisar diantara $1<\mathrm{H}^{\prime}<3$ maka dikategorikan cemar sedang dengan stabilitas komunitas biota sedang. Keadaan ini menunjukkan bahwa semakin tercemarnya suatu perairan, maka komunitas biota menjadi tidak stabil.

\section{KESIMPULAN}

Status mutu air sungai dan perairan Waduk Cirata dikategorikan dalam cemar sedang. Parameter kualitas air sungai yang melebihi baku mutu yaitu BOD, Nitrit, Klorin Bebas, Timbal, dan Fenol. Daerah genangan Waduk Cirata, parameter yang melebihi baku mutu adalah DO, BOD, Klorin Bebas, Timbal, dan Fenol. Besar total beban pencemaran dari 3 sungai yang masuk ke Waduk Ciarata adalah BOD sebesar 10,839 kg/hari, Nitrit sebesar 0,336 kg/hari, Klorin Bebas sebesar 16,685 kg/hari, Timbal sebesar $0,083 \mathrm{~kg} / \mathrm{hari}$ dan Fenol sebesar 0,008 kg/hari. Indeks keanekaragaman total plankton dan bentos di Desa Mande dan Margaluyu termasuk kategori cemar sedang. Di Desa Mande, spesies yang mendominasi fitoplankton yaitu Volvox $s p$ dan zooplankton yaitu Brachionus calyciflorus, sedangkan bentos spesies yang mendominasi yaitu Filopaludina sp. Di Desa Margaluyu, spesies yang mendominasi fitoplankton yaitu Volvox $s p$ dan zooplankton yaitu Moina $s p$, sedangkan bentos spesies yang mendominasi yaitu Macrobrachium sp.

\section{DAFTAR PUSTAKA}

[1] Basmi, J. (1999). Planktonologi: Plankton sebagai Bioindikator Kualitas Perairan. Fakultas Perikanan dan Ilmu Kelautan. Institut Pertanian Bogor.

[2] Canadian Council of Resource and Environment Ministers. (1987). Canada

[3] Davis, M. L. dan Cornwell, D. A. (1991). Introduction to Environmental Engineering. Second edition. Mc-Graw-Hill, Inc. New York.

[4] Guntur. (1993). Studi Perairan Sungai Brantas Dengan Menggunakan Makrozoobenthos Sebagai Indikator Pencemaran Lingkungan Perairan. Laporan Penelitian. Pusat Studi Lingkungan Universitas Brawijaya Malang.

[5] John, D.M. Whitton, B.A. and Brook, A.J. (2002). The freshwater algal flora of the British Isles: An identification guide to freshwater and terrestrial algae. The British Physiological Society, Cambridge, UK 702pp.

[6] Odum, E.P. (1993). Dasar-dasar Ekologi. Terjemahan Tjahjono Samingan. Edisi Ketiga. Yogyakarta: Gadjah Mada University Press.

[7] Moore, J.W. (1991). Inorganic Contaminants of Surface Water. Springer-Verlag. New York. Santrock, John. W. 2002. Life Span Development.Edisi 5. Jakarta: Erlangga.

[8] UNESCO/WHO/UNEP. (1992). Water Quality Assessments. Edited by Chapman, D. Chapman and Hall Ltd. London 
[9] Peraturan Pemerintah Nomor 82 Tahun 2001 tentang Pengelolaan Kualitas Air dan Pengendalian Pencemaran Air.

[10] PT. PJB UP Cirata, 2017. Laporan Akhir Pemantauan Kualitas Air Waduk Cirata Triwulan 12017. PT. PJB UP Cirata. Jawa Barat.

[11] Keputusan Menteri Negara Lingkungan Hidup Nomor 115 Tahun 2003 tentang Pedoman Penentuan Status Mutu Air.

[12] SNI 6989.57:2008 tentang Metode Pengambilan Contoh Air Permukaan.

[13] SNI 8066:2015 tentang Tata Cara Pengukuran Debit Air Sungai dan Saluran Terbuka menggunakan Alat Ukur Arus dan Pelampung, dengan prinsip velocity-area method. 